Nepalese Culture

Vol. XIV : 51-66, 2021

Central Department of NeHCA,

Tribhuvan University, Kathmandu, Nepal

DOI: https://doi.org/10.3126/nc.v14i0.35425

\title{
कीर्तिपुर क्षेत्रका लिच्छविकालीन मानव बस्तीहरू
}

\section{डा. महेश कुमार आचार्य}

सह-प्राध्यापक

नेपाली इतिहास, संस्कृति तथा पुरातत्त्व केन्द्रीय विभाग, त्रि. वि. कीर्तिपुर इमेल : mk99_acharya@yahoo.com

\section{लेख सार}

काठमाण्डौं उपत्यकाको दक्षिण पश्चिम क्षेत्रको डाँडोमा कीर्तिपुरसहर अवस्थित छ। पुरानो नेवार बस्ती र उनीहरूको भौतिक संस्कृतिका दृष्टिले समेत यो सहर सम्पन्न रहेको छ। सहरको ऐतिहासिकताको बारेमा वंशावलीहरूले यो सहर पूर्व मध्यकालमा राजा शिवदेवले निर्माण गरेको बताएको पाइन्छ।अध्ययनको कममा भने यस सहरका धेरै ठाउँमा लिच्छविकालका भौतिक अवशेषहरू पनि पाइएका छन्। हालसम्म पनि यो सहरमा नेपालको स्वर्ण युग मानिने लिच्छविकालमा मानव बसोबास रहेको थियो वा थिएन भन्ने विषयमा कुनै खोज हुन सकेको छैन। यसै पृष्ठभूमिमा यस क्षेत्रमा लिच्छविकालमा मानव बसोबास थियो वा थिएन ?, यदि मानव बसोबास रहेको भए कुन कुन क्षेत्रमा मानव बसोबास रहेको थियो ? भन्ने शोध प्रश्नको उत्तर खोज्ने उद्धेश्यले यो अध्ययन गरिएको हो। यस आलेखमा कीर्तिपुर क्षेत्रमा लिच्छविकालमा विकसित मानव बस्तीहरूको पहिचानलाई मुख्य उद्धेश्य बनाइएको छ। यो अध्ययन मूलतः अन्वेषणात्मक प्रकृतिको गुणात्मक र ऐतिहासिक अध्ययन भाएको हुँदा आवश्यक तथ्यहरू ऐतिहासिक तथा पुरातात्विक स्रोतहरूवाट संकलन गरिएको छ। विशेष गरेर लिच्छविकालीन मानव बस्तीको खोजी गर्नका लागि लिच्छवि अभिलेखहरूको अवस्थिति र अभिलेखमा वर्णित ठाउँ सम्बन्धी विवरणहरूबाट कतिपय तथ्यहरू संकलन गरिएको छ। त्यसवाहेक पुरातात्विक अन्वेषणवाट भेटिएका लिच्छविकालीन भौतिक अवशेष विषेशगरी मूर्ति, सालिक वा अन्य वास्तुसंरचनालाई पनि तथ्य संकलनको आधार बनाइएको छ। पुरानो मानव बसोवासको सड़केत गर्ने कतिपय मौखिक परम्परा वा किंवदन्तीहरू तथा आख्यानहरूबाट पनि केही तथ्यहरू संकलन गरिएको छ। यसबाहेक पूर्व प्रकाशित पुस्तक, लेख आदि द्वितीय स्रोतहरूबाट पनि आवश्यक तथ्यहरू संकलन गरिएको छ। यी तथ्यहरूलाई व्याख्या विश्लेषण गरेर हालको कीर्तिपुर क्षेत्रमा रहेका मानव बस्तीहरू मधये बाघभैरव, उमामहेश्वर क्षेत्र, चोभार, चारघरे, खा:सि बजार क्षेत्र र ट्याड्ला क्षेत्रमा लिच्छविकालमा मानव बसोबास रहेको तथ्य यस लेखको माध्ययमबाट प्रकाशमा ल्याइएको छ। यस बाहेक यहाँका पुराना भनिएका पाँगा, इटागोल आदि बस्तीहरू मध्यकालमा मात्र विकसित भएको तथ्य पनि यस अध्ययनवाट प्रकाशमा आएको छ। 
शब्द कुज्जी : कीर्तिपुर, लिच्छविकालीन मानव बस्ती, लिच्छविकालीन मूर्ति, लिच्छविकालीन चैत्य, लिच्छवि अभिलेख ।

\section{विषय परिचय}

कीर्तिपुर सहर काठमाडौदेखि करिव ७ कि.मि. दक्षिण पश्चिममा अवस्थित छ। काठमाण्डौं जिल्लाको चन्द्रागिरि नगरपालिकादेखि पूर्वतर्फ र ललितपुर उपमहानगरपालिकादेखि पश्चिमतर्फको भूभागमा फैलिएको यो एक नगरपालिका हो , जसको स्थापना सन् १९९७ मा पुराना ७ वटा गा.वि.स.हरू जोडेर भएको हो। १४.७६ वर्ग किलो मिटरमा फैलिएको र दशवटा वडाहरूमा विभाजित रहेको यस नगरक्षेत्र भित्र विशेष गरेर कीर्तिपुर, पाँगा, इटागोल तथा चोभार क्षेत्रमा विशेष पुराना नेवार बस्तीहरू रहेको छन्। हाल विद्यमान यी पुराना बस्तीको ऐतिहासिकता के हो ?, लिच्छविकालमा यी बस्ती थिए वा थिएनन् ? अथवा यस नगर क्षेत्र भित्रका कुन ठाँउमा लिच्छविकालमा मानव बस्ती रहेको थियो भन्ने प्रश्नको उत्तर खोजी गर्नु यस अध्यनको उद्धेश्य हो।

काठमाण्डौं उपत्यकाबाट विविध कारणले तलाउको पानी बाहिरिए पहि उपत्यका वरिपरिका पहाडी भू-भागमा बसोबास गर्ने पशुपालक कविलाहरू विस्तारै समतल उपत्यकामा आई बसोबास आरम्भ गरेको हुनसक्ने अनुमान इतिहासकारहरूको रहेको छ। कतिपय इतिहासकारहरूले प्राचिन समयमा यस क्षेत्रको वरिपरि नाग जातिका मानिसहरूको बसोबास भएको अनुमान गरेका छन् (पाण्डे र रेगमी, वि.सं.२०४४, पृ. १०६)। उनिहरूको उपत्यकामा वसोबास लिच्छविकालसम्म निरन्तर रहेको र लिच्छविराजा मानदेवले विवाह गरेकी पत्नी भोगिनी पनि नाग कन्या नै थिइन भन्ने विचारपनि केहि इतिहासकार हरूको रहेको छ (जोशी, वि.सं.२०७०, पृ. ४५६)। सायद यी असंगठित नाग जातिका बासिन्दाहरूलाई दक्षिणतिबाट आएका गोपाल, महिषपाल वंशीय शासकहरूले संगठित गरेर राज्य आरम्भ गरेको सङ्केत वंशावलीहरूले गरेका छन्।

कीर्तिपुरमा गाई-गोठ भन्ने अर्थ बुकाउने ‘सागल’ नामको टोल हालसम्म विद्यमान रहेको, गोठालाहरूको पोखरी अर्थ बुभाउने 'ग्वा:पुखू' नामको पोखरी रहेको र गोपाली थर लेख्ने नेवारहरूको बस्तीकीर्तिपुर र चोभार क्षेत्रमा हालसम्म रहेको आधारमा कतिपय इतिहासकारहरूले कीर्तिपुर क्षेत्रमा गोपालवंशको शासनकाल देखिनै गोपालहरू यस क्षेत्रमा बसोबास गर्ने गरेको अनुमान गरेका छन् (श्रेष्ठ, वि.सं.२०४७, पृ.३-४)। कीर्तिपुरको कोतघरमा बडा दशैको अवसरमाद्वादशीको दिनमा प्रधानहरूले गोपाली परिवारको प्रतिनिधिबाट टीका ग्रहण गर्ने परम्परा रहेको तथ्यबाट (कीर्ति अध्ययन तथा अनुसन्धान मण्डल, वि.सं.२०७३, पृ.२) पनि कीर्तिपुरमा गोपालहरूको ऐतिहासिक अस्तित्वलाई थप पुष्टि गर्दछ।

यसपछि, उपत्यकामा करिब ३२ पुस्तासम्म किरातवंशको शासन रहेको थियो। उनीहरूलाई पराजित गरेर भारतको वैशाली क्षेत्रबाट उपत्यकामा आएका लिच्छविहरूले काठमाण्डौं क्षेत्रमा सुन्दर मानव सभ्यता विकसित गरेका थिए । उनीहरूमा कलात्मक चेत, संगठित राज्यव्यवस्था, शैक्षिक उन्नति र कृषि, पशुपालन, उद्योग एवं व्यापार व्यवसयमार्फत् आर्थिक उन्नति गर्ने सार्मथ्य समेत रहेको तथ्य उनीहरूका अभिलेखहरूबाट प्रकाशमा आएको छ। त्यसैले लिच्छाविहरूको शासनकाल एक समुन्नत मानव सभ्यताको युग थियो भन्ने देखिन्छ। लिच्छविहरूले राखेका अभिलेखहरू गोरखा, धादिड्ज, चित्लाङ, काभ्रे आदि उपत्यका बाहिरका ठाउँबाट पनि पाइएको छ। यस आधारमा लिच्छावि सभ्यता उपत्यकामा मात्र सिमित थिएन अपितु उपत्यका बाहिर 
पनि विस्तार भएको थियो भन्ने देखिन्छ। यस युगमा ग्राम, तल र द्रड्ग नामका सामान्य, केही विकसित र घनाबस्ती भएका तीन किसिमका मानव बस्तीहरू रहेको तथ्यपनि उनीहरूका अभिलेखबाट प्रकाशमा आएको छ। उपत्यका भित्रै पर्ने कीर्तिपुरमा भने गोपालहरूको शासनकाल पछि, अर्थात् महिषपाल, किराँतकाल र लिच्छविहरूको शासनकालमा मानव बस्ती थियो वा थिएन भन्ने विषयमा गहन खोज हुन सकेको छैन ।

पूर्व मध्यकालतिर अर्थात् एघारौं शताब्दीको आखिरी समयका राजा शिवदेवलाई गोपाल वंशावलीले कीर्तिपुपर सहरको निर्माताको रूपमा व्याख्या गरेको छ। यसको अर्थ एघारौं शताब्दीमा कीर्तिपुर क्षेत्रमा व्यवस्थित सहर नै बनिसकेको थियो। तर लिच्छावि सभ्यताभने कीर्तिपुरसम्म विस्तार भएको थियो वा थिएन भन्ने प्रश्नको व्यवस्थित उत्तर हालसम्म प्राप्तहुन सकेको छैन। यो आलेखको मुख्य ध्येय यही उत्तरको खाजीमा केन्द्रित रहेको छ।

गोपालराज वंशावली तथा कतिपय प्राचीन अभिलेखमा यस क्षेत्रलाई जंगललेघेरिएको डाँडो वा बस्ती भन्ने अर्थमा गुंदे नाम दिइएको पाइन्छ। मध्यकालदेखि भने गौरवशाली सहर भन्ने अर्थमा यस सहरको नाम कीर्तिपुर रहन गएको विश्वास गरिन्छ। गोपालराज वंशावलीको पत्र २४ (क) माँने.सं. २१९ लागदा श्री शिवदेव राजा भएको र उनले कीर्तिपुरमा वलवल देवीको तपस्या गरेको, नहर बनाएको, ठाउँठाउँमा ढुड्गेधारा र पोखरी बनाएको" उल्लेख गरिएको छ (Bajracharya, \& Malla,1985, p.80)। यस आधारमा कीर्तिपुर सहरको निर्माता यी शिवदेवलाई मान्ने गरिएको हो। वंशावलीले उल्लेख गरे जस्तै ने.सं. २१९ मा शिवदेव नामका राजा थिए वा थिएनन् ? भन्ने तथ्यलाई विचार गर्दा सन् १०९९ देखि ११२६ सम्म नेपालमा शिवदेव नामका राजाले राज्यगरेको विवरण अन्य इतिहास लेखकहरूले पनि उल्लेख गरेको पाइन्छ (Slusser,1982, p.389)। यस आधारमा कीर्तिपुरमा व्यवस्थित मानव बसोबास गराउने राजाको रूपमा शिवदेवको नाम लिने परम्परा रहेको हो। पछिल्लो मध्यकालका मल्ल राजाहरूको समयमा मात्र यो सहरमा व्यवस्थित मानव सभ्यता विकास भएको देखिन्छ।

यसरी ऐतिहासिक तथ्यहरूले गोपालवंशकै शासनकालमा यस क्षेत्रमा मानव बस्ती बसिकेको सड्केत गर्ने, त्यसपछिको किराँत र लिच्छविकालमा मानव बसोबास रहे नरहेको कुनै तथ्य प्राप्त नहुने र निकै पछि, अर्थात् पूर्व मध्यकालदेखि मात्र पुन: यस क्षेत्रमा मानव बसोबास आरम्भ भएको र पछिल्लो मध्यकालमा मात्र यो सहरको रूपमा विकसित भएको देखिन्छ। यसो भए तापनि कीर्तिपुर क्षेत्रमा रहेका पुरातात्तिक तथ्यहरू र अभिलेखीय तथ्यहरूले मध्यकाल पूर्व नै यहाँका कतिपय स्थानमा मानव बसोबास रहेको सङ्केत गर्दछन्। त्यसैले गहन खोज अध्ययन नगरी यो पुरानो सहर कीर्तिपुरमागोपालहरूको शासनकालमा मानव बस्ती थियो तर लिच्छविकालमा यहाँ मानव बसोबास थिएन भन्ने निष्कर्षमा पुग्नु उपयुक्त हुँदैन । यस प्रसंगमा ऐतिहासिक र पुरातात्तिक साक्षीहरूले कीर्तिपुरको मानव बसोबासको ऐतिहासिकता बारेमा के सङ्केत गरेका छन्?, तथा कुन कुन क्षेत्रमा लिच्छविकालमा मानव बस्तीहरू रहेको हुन सक्छ ? भन्ने ऐतिहासिक तथ्यको अन्वेषणमा यो अध्ययन कार्य केन्द्रित रहेको छ। 


\section{अध्ययन विधि}

अनुसन्धानका स्वरूपका दृष्टिले यो अध्ययनकार्य अन्वेषणात्मक प्रकृतिको एक गुणात्मक अध्ययन हो । विषयका दृष्टिले भने यो एक ऐतिहासिक अध्ययन हो। त्यसैले यस अध्ययनका लागि तथ्यहरू पनि गुणात्मक र ऐतिहासिक विशेषता युक आवश्यक पर्दछ्। । यसकुरालाई आधार मानेर यो अध्ययनका लागि आवश्यक तथ्यहरू प्राथमिक र द्वितीय स्रोतहरूबाट संकलन गरिएको छ। प्राथमिक स्रोत अन्तर्गत कतिपय तथ्यहरू यस क्षेत्रका पुरातात्तिक स्थलहरू र पुराना स्मारक एवं कलाकृतिहरूको विषयमा स्थलगत अन्वेषण गरेर, केही तथ्यहरू कीर्तिपुर क्षेत्रको जानकार विज्ञहरूसँगको अन्तर्वार्ताबाट तथा, यहाँका पुराना भौतिक सम्पदाहरूको अवलोकन आदिबाट संकलन गरिएको छ। त्यसै गरी द्वितीय स्रोत अर्न्तगतका पूर्व प्रकाशित लिच्छवि अभिलेखहरू, पुस्तक, पत्रिकाहरूबाट र कतिपय तथ्यहरू भने प्रकाशित अप्रकाशित आख्यान एवं किंवदन्तीहरूबाट पनि संकलन गरिएको छ। किंवदन्ती र द्वितीय स्रोतहरूले कुन क्षेत्रमा पुरानो बस्ती रहेको सङ्केत गरेका छन्? भन्ने विषयमा सूचना संकलन गरिएको छ। यी स्रोतहरूले सड्केत गरेका पुराना बस्तीहुन सक्ने संभावित स्थलहरूमा स्थलगत अन्वेषण गरेर ती बस्ती रहेको पुष्टी गर्नलाई के कस्ता लिच्छविकालीन भौतिक प्रमाणहरू रहेका छन्? भन्ने कुराको खोजी गरिएको छ। अन्वेषणबाट प्राप्त भौतिक अवशेषहरू लिच्छविकालीन हुन् होइनन् भन्ने यकिन गर्न पूर्व प्रकाशित पुस्तक र लेखहरू तथा संस्कृति विषय र पुरातत्व विषयका विषय विज्ञ एवं प्राध्यापकहरूसँग अन्तरर्वार्ता लिएर पनि तथ्यहरू संकलन गरिएको छ। लिच्छविकालीन भौतिक अवशेष पाइएका ठाउँहरूलाई आधार मानेर कुन कुन ठाउँमा त्यसवेलाको बस्ती थियो भन्ने तथ्यलाई पुष्टि गरिएको छ। यसरी मौखिक परम्परा, लिच्छविअभिलेख, लिच्छाविकालीन भौतिक अवशेष तथा पूर्व प्रकाशित सामग्रीहरूका आधारमा त्यस समयका मानव बस्ती पहिचान गर्ने विधि अवलम्बन गरिएको छ।

यस अध्ययनकार्यलाई भौगोलिक रूपमा हाल विद्यमान कीर्तिपुर नगरपालिकामा मात्र सिमित (Delimit) गरिएको छ। अर्थात् हालको कीर्तिपुर नगरपालिका क्षेत्र भित्रका संभावित लिच्छविकालका मानव बस्तीको खोजीमा मात्र यो अध्ययन सीमित रहेको छ। विषयगत रूपमा यस नगरपालिका क्षेत्रमा लिच्छविकालीन मानव बस्ती रहेका ठाङँको खोजीमा मात्र केन्द्रित गरिएको छ बस्ती बाहेक लिच्छविकालका अन्य पक्षको अध्ययन यसमा परेको छैन। त्यसै गरेर यस अध्ययनबाट प्रकाशमा आएका तथ्यहरूका कतिपय सीमाहरू (Limitation) रहेका छन्। लिच्छविकालीन मानव बस्ती खोजीकार्यका लागि पुरातात्तिक उत्वनन् र त्यस्ता उत्वनन्बाट प्राप्त भौतिक अवशेषहरूको निरपेक्ष तिथि निर्धारणबाट मात्र वास्तविकता प्रकाशमा आउन सक्दछ। समय, साधन र स्रोतको अभावले यस अध्ययनमा उत्वनन् र भौतिक अवशेषको निरपेक्ष तिथि निर्धारण गर्न सकिएको छैन । अन्वेषणको ऋममा जमिनको सतहमा पाइएका लिच्छविकालीन भौतिक अवशेषको प्राप्तिको आधारमा सो क्षेत्रमा लिच्छविकालीन मानव बसोबास थियो भन्ने निष्कर्षमा पुगदा कहिले काहीं त्यस्ता अवशेषहरू पछिल्लो समयमा स्थान परिवर्तन भएको पनि हुन सक्दछ। यस्तो अवस्थामा प्राप्त निष्कर्षमा केही तलमाथि पर्ने हुन सक्छ यी कुरालाई यो अध्ययनकार्यको परिणाममा देखापर्न सक्ने सीमा (Limitation) मानिएको छ। 


\section{मुख्य प्राप्ति}

लिच्छविकालका मानव बस्तीहरूको विस्तृत जानकारी दिने प्रमुख आधारहरू तात्कालीन अभिलेखहरू हुन् । त्यसवेला अभिलेखहरूको वर्णनको आधारमा कीर्तिपुरको पश्चिमतर्फ चन्द्रागिरिदेखि दहचोक बीचको क्षेत्रलाई लिच्छवि अभिलेखमा शीताटिका तल भनिएको छ। त्यसवेलाको तल गाउँ भन्दा विकसित बस्तीर एक प्रशासनिक एकाइ थियो जस अन्तर्गत धेरै गाउँहरू पर्दथे र यस शीताटिका तल भित्र पनि त्यसवेलाका टेग्वल, किचप्रिचिड्, काद्रुड्, बु.ड् (बीचको अक्षर नबुभिने) आदि गाउँहूू पर्दथे (वज्राचार्य, वि.सं. २०४३, पृ.१९५) । लिच्छवि अभिलेखहरूको वर्णनबाट कीर्तिपुर क्षेत्रमा कुनै गाउँ रहे नरहेको भने थाह पाउन सकिएको छैन ।

लिच्छवि अभिलेखको वर्णनमा कीर्तिपुरक्षेत्र भित्र मानव बसोबासको सङ्केत नपाइएको अवस्थामा मानव बस्ती खोज्ने अर्को आधार लिच्छवि अभिलेखको प्राप्ति स्थल पनि हुन सक्छ। किनभने लिच्छवि अभिलेखहरू सामान्यतया मानव बस्ती आसपासका सार्वजनिक स्थलहरूमा राख्ने गरिएको पाइन्छ। कीर्तिपुर आसपासका ललितपुर, फर्पिड, बलम्बु, चौकीटार, सतुड्गल,मच्छेगाउँ, आदि क्षेत्रबाट लिच्छवि अभिलेख पाइएको छ। यस आधारमा कीर्तिपुरको वरिपरिका भू-भागमा लिच्छविकालमा मानव बस्ती रहेको देखिन्छ। वर्तमान कीर्तिपुर नगरपालिका क्षेत्र भित्रबाट एकमात्र लिच्छवि अभिलेख पाइएको छ जुन यहाँको पुरानो बस्तीहरूभन्दा केही टाढा चारघरे क्षेत्रमा पाइएको छ। यसरी हेर्दा अभिलेखकै आधारमा हाल विद्यमान रहेका कीर्तिपुरका कीर्तिपुर, पाँगा, चोभार, ईटागोल जस्ता पुराना बस्तीहरूमा लिच्छविकालमा मानव बसोबासको सङ्केत प्राप्त गर्न सकिएन । त्यसैले अभिलेखका अतिरिक्त यस अध्ययनका ऋममा प्राप्त अन्य पुरातात्विक वस्तुहरू, लोक विश्वास तथा पूर्वप्रकाशित अध्ययन सामग्रीहरूसमेतको आधारमा लिच्छविकालीन मानव बसोबासको खोजी गर्नुपर्ने अवस्था रहेको देखिन्छ। यस अध्ययनको कममा प्राप्त विभिन्न तथ्यहरूले निम्न क्षेत्रहरूमा लिच्छविकालीन मानव बस्तीहरू रहेका कुरा सङ्केत गरेका छन्।

बाघभैरव क्षेत्र : बाघभैरव मन्दिर कीर्तिपुर सहरको मध्यभागमा अवस्थित मध्यकालीन मन्दिर हो । एघारौँ शताब्दीमा शिवदेवले स्थापना गरेको विश्वास गरिए तापनि यो मन्दिरसँग सम्बन्धित पहिलो लिखित प्रमाण ने.सं. ६३५ अर्थात् सन् १५१५ मा जगतपाल वर्मालेयसको जिणोद्वार गरेको विवरण सहितको अभिलेख हो (Shrestha, 1994, p.80)। यसबाट कम्तिमा सोह्रौं शताब्दी अघिनै यो मन्दिर निर्माण भैसकेको स्पष्ट हुन्छ। तर यो मन्दिर परिसरमा रहेका केही मूर्तिहरूले यो क्षेत्रमा गोपालहरूको राज्यकालदेखि निरन्तर मानव बस्ती रहेको क्षेत्र थियो भन्ने देखिएको छ। कीर्तिपुर र चोभारमा रहेको गोपालीहरूको बसोबास, गाईगोठ बुभाउने सागल टोल र गाईले पानी खाने पोखरी अर्थ लाग्ने ग्वा:पुखू बाघभैरव मन्दिर आसपासमा गोपालकालीन मानव बसोबासको सङ्केत गर्ने आधार हुन्। यसबाहेक चोभार फँंदीमा (वाग्मति र नख्खुको दोभाना रहेको गवा:दिप(गोपाल मसान), ग्वा:ननि (गोपाल चोक), ग्वा: छें (गोपाल घर), गाई बाँध्न राखेको ढुड्गा र हसियाँमा धार लगाउने ढुड्गा गोपालकालीन मानव बस्तीको अवशेषको रूपमा हालसम्म विद्यमान रहेका छन् (कीर्ति अध्ययन तथा अनुसन्धान मण्डल, वि.सं. २०७३, पृ.१)। यी सबै बाघभैरव क्षेत्र र आसपासमा रहेका छन् । यसै गरी यस मन्दिर परिसरमा रहेको गणेश मन्दिरभित्र सप्तमातृकाका मूर्तिहरू, गणेशको मूर्ति, उधर्व लिड्ग शिव, तथा शिवपार्वतीको मूर्तिहरू रहेका छन्। यसै गरी यहीमन्दिरको प्राड्गणमा एक नन्दीको सालिक र बासुकी भनिने शिवको खण्डित मूर्ति रहेको छ। यी मूर्तिहरूको प्राचीनतालाई हेर्दा लैनसिंह वाड्देलले सप्तमातृकाका 
मूर्तिहरूलाई तेस्रो शताब्दीका मूर्ति $(1982$, p.28) र उधर्व लिड्ग शिवको मूर्तिलाई चौथो शताब्दीको भनेका छन् (1982, p.54)। यसै गरी शुक्रसागर श्रेष्ठले यहाँको शिवपार्वतीको मूर्तिलाई चौथो शताब्दीको आखिरीतिरको मूर्ति भनेका छन् (Shresthe, 1994, p.193)। यी मूर्तिहरूले यो क्षेत्रमा लिच्छविकाल पूर्वदेखिनै मानिसहरूको बस्ती रहेको सङ्केत गर्दछ् ।

बाघभैरव मन्दिर परिसरमा रहेका गणेश मन्दिरभित्रको गणेशको मूर्ति, मन्दिरको आँगनमा रहेका नन्दीको सालिक, तथा बासुकी भनिने शिवको खण्डित र अर्धनिर्मित मूर्तिलाई कला समीक्षकहरूले लिच्छविकालीन भौतिक वस्तु स्वीकार गरेका छन् । यहाँको गणेशको मूर्तिलाई वाङ्देलले छैटौँ सातौं शताब्दीको मूर्ति भनेका छन् (1982, p.27) भने वासुकी भनिने शिवको खण्डित मूर्तिलाई र बाघ भैरव मन्दिर प्राड्गणमा रहेको नन्दीको सालिकलाई शुक्रसागर श्रेष्ठले छैटौँ शताब्दीको आरम्भतिरको बताएका छन् (Shrestha, 1994, p.197-198)। यी मूर्ति तथा सालिकहरूलाई प्रत्यक्ष अवलोकन गर्दा पनि वाङ्देल तथा श्रेष्ठले गरेको तिथि निर्धारण सत्य लागदछ। समयका हिसाबले छैटौं शताब्दी लिच्छवि सभ्यताको चरम उत्कर्षको समयहो। यस युगमा यतिधेरै मूर्तिहरू पक्कै पनि निर्जन जंगलमा नभै मानव बस्तीकै आसपासमा दैनिक पूजा आराधनाको लागि स्थापना गरिए होलान् । यी मूर्तिहरू सायद लिच्छविकालमा बाघ भैरव क्षेत्र आसपासको लिच्छविकालीन मानव बस्तीलाई लक्षित गरी स्थापना गरिएको देखिन्छ। यी पुरातात्तिक प्रमाणहरूले बाघ भैरव मन्दिर आसपासको क्षेत्रमा कुनै न कुनै रूपमा मानव बस्ती रहेको स्पष्ट भएको छ। यस पछि पनि यहाँ मानव बसोबासको इतिहास निरन्तर रहिरह्यो ।

उमामहेश्वर मन्दिर क्षेत्र : कीर्तिपुर डाँडोकोशिखरमा उमामहेश्वर नामको छाने शैलीको मन्दिर रहेको छ। स्थानीय बासिन्दाहरू भने यस मन्दिरलाई क्वा:च्व देग: भन्दछन् जसको शाव्दिक अर्थ डाँडाको टुप्पोमा रहेको कोत परिसरको देवता भन्ने हुन्छ (श्रेष्ठ, वि.सं. २०४७, पृ. ४७)। मध्यकालीन मल्ल राजाश्रीनिवास मल्ल र उनको छोरा योगनरेन्द्र मल्लको राजदरबार रहेको लायकूटोलदेखि ठीकमाथि यो मन्दिर रहेको छ। यहाँ प्राप्त ताम्रपत्र अनुसार मन्दिरको निर्माण पाटन तुम्बहालका शक्तिपात्र विश्वनाथ बाबुले ने.सं ७७५ (सन् १६४५ ) मा बनाएका थिए (श्रेष्ठ, वि.सं. २०४७ , पृ. ४९-५०)। मन्दिरको ठीक पश्चिमतर्फ मध्यकालीन एक कोतघर रहेको छ। कीर्तिपुरको शिखरमा रहेको यो कोत मध्यकालमा सामरिक दृष्टिले महत्वपूर्ण थियो। त्यसैले मल्लराजाहरूले यस क्षेत्रलाई राजदरबार बनाउन उपयुक्त ठाउँ माने होलान्। भौगोलिक रूपले मानव बसोबास योग्य रहेको र मल्ल राजाहरूले दरबार स्थापनाका लागि योग्य ठहराएको यो स्थलमा मध्यकालभन्दा अधि कुनै मानव बस्ती रहे नरहेको तथ्य बताउने लिखित प्रमाण भने पाउन सकिएको छैन। त्यसैले यस क्षेत्रमा लिच्छविकालमा मानव बस्ती रहे नरहेको यकिन गर्न कुनै अलिखित भौतिक वस्तुहरूको वा कुनै पुरातन परम्पराको अस्तित्व खोजी गर्नुपर्ने अवस्था रहेको छ।

कीर्तिपुरको विषयमा गहिरो अध्ययन गर्ने अध्ययता शुक्रसागर श्रेष्ठले कीर्तिपुरको ग्वा:पुखूसँग सम्बन्धित रहेको रहाल बन्द भएको एक पुरातन परम्पराको उल्लेख आफ्नो पुस्तकमा गरेका छन् । पुस्तकमा उल्लेख भए अनुसार घण्टाकर्णका दिनश्रावण कृष्ण चतुर्दशीमा ग्वा:पुखूबाट गोपालीहरूले वलि दिनको लागि भेडो लगेर लायकू क्षेत्रको कुनामा रहेको एक अमूर्त ढुड्ग्गामा मन्साउनु पर्ने पुरानो परम्पराको वर्णन गरेका छन् (श्रेष्ठ, वि.सं.२०४७, पृ. ४)। यो पुरानो परम्पराले उमामहेश्वर मन्दिर क्षेत्र अर्थात् लायकू क्षेत्रमा गोपालहरूको कुनै 
न कुनै धार्मिक सम्बन्ध रहेको देखिन्छ। भँंडो मन्साउने अमूर्त (aniconic stone) ढुड्गो सायद गोपालहरूको समयकालतिरको कुनै प्रतीकात्मक धार्मिक प्रस्तर हुन सक्छ। काठमाण्डौं उपत्यकामा आरम्भिक समयमा पूजागरिने वस्तु यस्तै बलष्अयलष्अ अमूर्त वस्तु हुने गर्दथ्यो (Shokoohy, Shokoohy \& Shrestha, 2014,p.23)। यसको अर्थ यस क्षेत्रमा गोपालकालमै मानव बसोबास रहेको हुन सक्ने कुराको सङ्केत हो। गोपालकालमा मानव बस्तीको सड्केत पाइने र मध्यकालमा मानव बसोबास भएको प्रमाणित हुने यस क्षेत्रबाट लिच्छविकालमा मात्र मानव बस्ती हट्नुपर्ने कुनै विशेष कारण देखिदैन ।

उमामहेश्वर मन्दिरदेखि पश्चिममा रहेको कोतघर क्षेत्रमा सन् १९६१ मा पानी ट्याङ्की निर्माणको लागि जमिन खन्ने ऋममा एक शिवको मूर्ति प्राप्त भएको छ। पन्ध्र सेन्टिमिटर उचाईरहेको ध्यान मुद्रामा बसेको यो शिव मूर्तिको अव्यवस्थित उत्वनन्को कममा क्षति पुग्न गएको छ। मूर्तिको छाती, दाहिने हात, आभामण्डल ₹ आधार ढुड्गा (Pedestal)मा समेत क्षति पुग्न गएको र खण्डित हुन पुगेको यो मूर्तिको प्राचीनता पहिचानको लागि शुक्र सागर श्रेष्ठले निकै मेहनत गर्नु भएको छ। भारतको एलोरा गुफाका समकालीन मूर्ति, भारतको कर्नाटकको वदामी क्षेत्रका मूर्ति, बाघभैरव क्षेत्रकै गणेश मन्दिरका मातृकाका मूर्तिहरूका वस्त्र, आभूषण, अनुहार आँखा आदिको तुलनात्मक अध्ययन गर्दे उनले यस शिव मूर्तिलाई सातौँ वा आठौँ शताब्दीको मूर्ति भनेका छन् (Shrestha, 1994,p.198)। यसबाट यो मूर्ति लिच्छवि सभ्यताको उत्कर्षकालमै बनेको थियो। पक्कै पनि तात्कालीन मानवबस्तीकै छेडमा पूजा आजाको लागि यो मूर्ति स्थापना गरिएको हो भन्ने सहजै अनुमान गर्न सकिन्छ। यसबाट उमामहेश्वर मन्दिर बन्नुभन्दा हजारौंवर्ष पहिलेदेखि अर्थात् लिच्छाविकालमै यस क्षेत्रमा कुनै न कुनै रूपमा मानव बसोबास रहेको थियो भन्न सकिन्छ। सर्वोच्च भागमा शिवालय स्थापना गरेर यसको आसपासका क्षेत्रमा अर्थात् हालको लायकू क्षेत्रमा लिच्छविहरूको बस्ती रहेको हुन सक्ने आधार यो मूर्ति र यस क्षेत्रसँग जोडिएको भेडो मन्साउने पुरानो परम्पराले सड्केत गरेका छन् ।

चोभार क्षेत्र : कीर्तिपुर नगरपालिका वार्ड नं. ६ मा अवस्थित चोभार क्षेत्रमा मानव बसोबासको इतिहास ज्यादै पुरानो देखिन्छ। यहाँ अवस्थित आदिनाथ मन्दिरसँग सम्बन्धित रहेका धेरै लोकोक्ति तथा किंवदन्तीहरू नाग, गाई र गोठालासँग सम्बन्धित रहेको पाइन्छ। गोपाली थरका नेवारहरूको बसोबास हालसम्मपनि यस क्षेत्रमा रहेको छ। यी तथ्यलाई विचार गर्दा दक्षिणतिरबाट उपत्यकामा प्रवेश गरी संगठित राज्य स्थापना गर्ने गोपालवंशका पशुपालकहरू यसक्षेत्रमा बसोबास गरेको अनुमान गर्न सकिन्छ। चोभार क्षेत्रको गल्छीबाट उपत्यकाको पानी बाहिरिएपछि, संभवत चोभार डाँडाको उपल्लो भागमा आदिवासी पशुपालक गोपालवंशी कविलाहरूबसोबास गरेको हुन सक्ने तथ्य यहाँका किंवदन्तीहरूबाट बुक्न सकिन्छ। त्यसैगरी मध्यकालमा यहाँ उन्नत मानव सभ्यताको विकास भएको तथ्य, यस क्षेत्रमा हालसम्म यथावत रहेको मध्यकालीन नेवार बस्ती, आदिनाथ मन्दिर र यस मन्दिर परिसरमा रहेका मध्यकालीन अभिलेख, चैत्य, मूर्ति तथा मन्दिरहरूले प्रमाणित गर्दछ् । यसो भएतापनि लिच्छविवकालमा भने यहाँ मानव बसोबास रहे वा नरहेको विषयमा स्पष्ट प्रमाणित गर्ने कुनै लिखित आधार भेटिएको छैन। त्यसैले यहाँको लिच्छविकालीन मानव बसोबासको यथार्थ अवस्था थाहापाउन यहाँ कुनै लिच्छविकालीन मानवका भौतिक अवशेष रहे नरहेको विषयमा अध्ययन गर्नु आवश्यक देखिन्छ। 
यस अध्ययनको कममा प्रत्यक्ष प्रमाण नपाइएतापनि चोभार क्षेत्रमा लिच्छविकालमा पनि मानव बसोबास रहेको बताउने केहीपरोक्ष प्रमाणहरू भने पाइएका छन् । चोभार आदिनाथको उत्पत्तिको प्रसंगमा व्यजल १यअपनामक लेखकले आफ्नो पुस्तक करुणामयमा इन्द्र रत्न वज्राचार्यको भनाई उधृत गर्दे उल्लेख गर्दछन् कि आदिनाथ सम्प्रदायको मौलिक परम्परा लिच्छवि राजा अंशुवर्माको पालादेखि शुरु भएको हो (ज्डण, उ।घछछ)। यो भनाई कुनै ऐतिहासिक तथ्यमा आधारित नभए तापनि यो भनाइले यहाँका रैथानेहरूमा चोभार क्षेत्रमा लिच्छविकालमा मानवबसोबास रहेको र तिनै लिच्छविकालीन चोभारे जनताले अंशुवर्माको राज्यकालमा आदिनाथ सम्बन्धि धारणा विकसित गरी यहाँ आदिनाथको स्थापना गरेको कुरामा विश्वास गर्दछन् भन्ने कुरालाई सड्केत गर्दछ ।

लिच्छविकालका अभिलेख चोभार क्षेत्रबाट नपाइएतापनि धनवज्र वज्राचार्यले स्वयंभूनाथ, पशुपतिनाथ, वज्रयोगिनी आदि देवस्थल जस्तै चोभार आदिनाथ क्षेत्र पनि त्यसवेला एक वनदुर्गको रूपमा रहेको उल्लेख गरेका छ.् (वि.सं. २०४३, प्.9९)। उनैले चारै तिरबाट पहाडले घेरिएको मानव बस्तीगिरि दुर्ग हो भने चारै तिरबाट जंगलले घेरिएको मानव बस्ती वनदुर्ग हो र यस्ता दुर्गभित्र निश्चित सीमा तोकिएको कोट्टहरू अर्थात् मानव बस्तीहरू रहेका हुन्थे भनेका छ, (प्. २३६)। यसबाट लिच्छविकालमा चोभार डाँडाको चारैतिर जंगलले घेरिएको र पहाडको टुप्पोमा मानव बसोबास रहेको र संभवत त्यहाँ देवस्थलपनि रहेको थियो भन्ने बुभ्कन सकिन्छ।

यी परोक्ष आधारहरूबाहेक चोभार क्षेत्रमा लिच्छाविकालीन केही भौतिक अवशेषहरू पनि प्राप्त भएका छन्। चोभार आदिनाथ मन्दिरबाहिर पूर्व आँगनमा करिब चारफिट अग्लो एउटै प्रस्तरलाई कुँदेर बनाइएको एक चैत्य रहेको छ। कुनै शिवलिड्ग्गको जलहरी जस्तो ढुड़ग्गोको आधारमाथि राखिएको यो चैत्य भारतीय क्षेत्रमा चैत्यवास्तुकलाको विकाबक्रमको आरम्भिक समयमा निर्माण भएको जस्तो देखिन्छ। कलात्मकता दृष्टिले र शैलीका दृष्टिले उस्तै देखिने एउटै प्रस्तरबाट निर्मित तर आकारमा केही साना थप चारवटा चैत्यहरू केही पूर्वतर्फ रहेको मध्यकालीन अर्को चैत्यको चारै कुनामा राखिएका छन् । यी पाँचवटै चैत्यको शीर्षभागमा भुवन तथा गजुर जस्तो आकृति पछि, थप गरिएको स्पष्ट देखिन्छ । बाँकि संरचना एउटै प्रस्तरबाट निर्मित छ, र चैत्यको गर्भभागको प्रस्तर विशेष चिल्लो परिएको छ। संस्कृति विषयका एक शोधार्थीले चोभार क्षेत्रका यी एउटै प्रस्तरबाट निर्मित चैत्यहरूको वास्तुशैली पाँचौं देखि आठौँ शताब्दीमा निर्मित लिच्छ,विकालीन चैत्यसँग मिल्दो जुल्दो देखिन्छ भनेकी छिन् (Maharjan, 2003, p.21) । काठमाण्डौं उपत्यकाका लिच्छविकालीन चैत्यहरूको गहिरो अध्ययन गर्ने Niels Gutschow ले सातौंदेखि नवौं शताब्दी तिरका काठमाण्डौंको टेकु, चावहिल, स्वयंभू आदि स्थानबाट प्राप्त लिच्छविकालीन चैत्यको गर्भ (Dome) को रेखाचित्र प्रस्तुत गरेका छन् $(1997, \mathrm{p} .115)$ यी चैत्यका गर्भ र चोभार क्षेत्रका चैत्यहरूको गर्भको आकारमा केही भिन्नता भए तापनि शैलीमा निकै समानता रहेको देखिन्छ। यसबाट पनि चोभार क्षेत्रका यी चैत्यहरू लिच्छविकालीन हुन भन्ने देखिन्छ। कीर्तिपुर क्षेत्रको विशेष अध्ययन गरेका शुक्र सागर श्रेष्ठले यी चैत्यका आधारमा लिच्छविकालमा चोभार क्षेत्रलाई बौद्वमार्गीहरूको बसोबास क्षेत्रमा विकास गरिएको निष्कर्ष निकालेका छन् (श्रेष्ठ, वि.सं. २० $७$, पृ. $Y$ ) । पछिल्लो समयमा कीर्तिपुर क्षेत्रको सांस्कृतिक सम्पदाको अध्ययन गर्नु हुने अध्ययताद्वय श्रेष्ठ र शर्माले पनि यो चैत्यलाई लिच्छविकालीन चैत्यको रूपमै व्याख्या गर्नु भएको छ (श्रेष्ठ र शर्मा, ने.सं.११३९, पृ.१२९)। यी लिच्छविकालीन चैत्यको प्राप्तिका आधारमा पनि चोभार क्षेत्रमा मानव बस्ती थियो भन्ने देखिन्छ। 
चारघरे क्षेत्र : कीर्तिपुर नगरपालिकाको वार्ड नं. ६ मा एक चारघरे नामको नयाँ बस्ती रहेको छ। हाल बाक्लो मानव आवादी रहेतापनि कुनै समय चारवटामात्र घर रहेको सुनसान बस्ती भन्ने अर्थमा यसक्षेत्रलाई चारघरे नामकरण गरिएको विश्वास गरिन्छ। हालको यस क्षेत्रमा सयवर्षको इतिहास बोकेका कुनै पनि घर रहेका छैनन् । यस क्षेत्रमा पाइएका मूर्ति तथा अन्य भौतिक अवशेषहरू पनि मध्यकालभन्दा अधिका छैनन् । यस्तो अवस्थामा यस क्षेत्रमा लिच्छविकालमा मानव बस्ती रहे नरहेको यकिन गर्नु निकै चुनौतीपूर्ण काम हो । यसो भएतापनि यहाँ प्रचलनमा रहेका केही किंवदन्तीहरू, यहाँबाट प्राप्त भौतिक अवशेष र यस क्षेत्रमा प्राप्त एक अभिलेखले यहाँ लिच्छाविकालमा मानव बसोबास रहेको थियो भन्ने देखिएको छ।

हरिसिद्धि देवीको सम्बन्धमा चारघरे क्षेत्रमा हालसम्म एक किंवदन्ती प्रचलनमा रहेको पाइएको छ। पाटनमा हरिसिद्धिको स्थापना हुनुअघि यी देवी कीर्तिपुर चारघरे क्षेत्रमा स्थापना गरिएको थियो। कुनै कारणले देवी यहाँका बासिन्दाहरूसँग कुद्ध भएको कारणले यहाँ उडूसको ठूलो प्रकोप देखापर्यो। देवी रिसाएको र यहाँ बस्न इच्छा नगरेपछि, हरिसिद्धिलाई पाटन लगियो। यो किंवदन्तीले यस क्षेत्रको प्राचीनता बारेमा केही सङ्केत गरेको देखिन्छ। हरिसिद्धि विक्रम सम्वत्को संस्थापक मानिने भारत उज्जैनका राजा विक्रमादित्यको पालामा उज्जैनमा स्थापना भएको र यिनलाई नेपाल ल्याएर आरम्भमा बानेश्वर क्षेत्रमा स्थापना गरिएको थियो । लिच्छविकालमा वि.सं.७४५ तिर यी देवीलाई पाटनमा स्थापना गरिएको विश्वास गरिन्छ (Maharjan, n.d., p.3)। यसरी पाटनमा हरिसिद्धिको स्थापनाको समय लिच्छविकाल अर्थात् सातौं शताब्दी मान्ने गरिएकोमा सो भन्दाअधि हरिसिद्धि चारघरे क्षेत्रमा रहेको भन्ने आख्यानका आधारमा यसक्षेत्रमा लिच्छविकालमा पनि कुनै न कुनै रूपमा मानव बस्ती रहेको थियो भन्ने कुराको सड्केत मान्न सकिन्छ।

हाल चारघरे क्षेत्रको जाल्पा देवी मन्दिर परिसरमा यक्षको मूर्ति प्राप्त भएको छ। स्थानीय बासीहरूले पोते देवता पनि भन्ने गरेको भारवाहक देवताको यो मूर्ति कुनै भारले थिचिएको मानव आकृतिको रूपमा चित्रण गरिएको छ। यस आकृतिलाई श्रेष्ठ र शर्माले यक्षको मूर्ति भन्नु भएको छ र यसलाई लिच्छविकालीन कलाकृतिको रूपमा व्याख्या गर्नु भएको छ (श्रेष्ठ र शर्मा, ने.सं.११३९, पृ. १२६)। भिन्न प्रसंगमा साँखु क्षेत्रका ढुड्गेधारामा भएका यस्तै कलकलाकृतिको ऐतिहासिकताको वर्णन गर्ने कममा लेखक दूयले दाह्री सहितका यक्षमूर्तिहरू पूर्व लिच्छाविकालका र अन्य यक्षहरू उत्तर लिच्छाविकालका कलाकृतिहरू भएको बताउनु भएको छ. (Sharma \& Shrestha, 1916, p.100) । अन्य कला समीक्षकहरूले पनि यस्ता यक्षका आकृतिहरूलाई लिच्छविकालका कलाकृति बताएका छन् (Slusser,1982, p.361)। यी आकृतिहरू ढुड्गेधाराको तल्लो भागमा, कुनै देव मूर्तिको आधार ठुड्गोमा वा कतै मन्दिरको थाम र टुँडालको तल्लो भागमा बनाइएको पाइन्छ। स्वतन्त्र मूर्तिको रूपमा नभै कुनै ठूलोमूर्ति वा अन्य कलाकृतिको आधारमा यी कलाकृति बनाइएको पाइने भएको हुँदा यसका साथै यस क्षेत्रमा अन्य कुनै कलाकृति पनि थियो होला भन्ने अनुमान गर्न सकिन्छ। व्यवस्थित उत्वनन् नभएको हुँदा यस्ता अन्य कलाकृति प्राप्त नभएको पनि हुन सक्छ। जे होस यो भौतिक प्रमाणले पनि लिच्छविकालमा यस क्षेत्रमा मानव बस्ती रहेको कुरालाई नै सङ्केत गर्दछ,।

यस क्षेत्रमा लिच्छविकालीन मानव बस्तीको सड्केत गर्ने अर्को भरपर्दो प्रमाण यहाँ रहेको लिच्छविकालीन अभिलेख पनि हो। चारघरेको जाल्पादेवी मन्दिर नजिकै रहेको एक पिपलको बोटमुनि एक शिलापत्र अभिलेख रहेको छ। अक्षरहरू खिइएर पढ्न नसकिने यो अभिलेखका केही अक्षरहरू मात्र पढ्न सकिने अवस्थाका छन्। वि.सं. 
२०३० सालमै यो अभिलेखलाई हरिराम जोशीले प्रकाशित गरिसक्नु भएको थियो (जोशी, वि.सं. २०३०, पृ. ३५१)। यस पहि, यो अभिलेखलाई सन् १९६३मा डिल्लीरमण रेग्मीले पनि आफ्नो पुस्तक Inscriptions of Ancient Nepal मा प्रकाशित गुर्न भएको थियो (Regmi,1983,p.69)। यतिवेला यो अभिलेख राम्रोसँग पढ्न नसकिएको बुक्किन्छ। लेखकहरूले लिड्वल र शोल्ल अघिकरणको उल्लेख भएको यो कुनै ग्रामबासीलाई केहीकुरा निगाह भएको लिच्छविकालीन अभिलेख भएको मात्र बताउन सकेका छन्। यही अध्ययनको क्रममा लिपिविद्श्याम सुन्दर राजवंशीसँगको अन्तर्वार्ताको क्रममा उनले यो अभिलेखको थप पाठ पढ्न सकिएको बताएका छन् । यस अभिलेखको पाँचौ पड्क्तिमा राजा शिवदेवको नाम र बुड्पा ग्रामको नाम पढ्न सकिएको, आठौँ पड्क्तिमा सामन्त अंशुवर्माको नाम पढ्न सकिएको र यो संभवत अंशुवर्मा महासामन्त हुनु अघिको अर्थात् सम्वत पू५ आषाढ महिनाको अभिलेख हुन सक्ने बताएका छन् (राजवंशी, व्यक्तिगत् अन्तरवार्ता, कार्तिक १३, वि.सं. २०७७)। यो अभिलेख र यसमा उल्लेखित व्यहोराबाट लिच्छविकालमा कीर्तिपुर चारघरे क्षेत्रमा बुड्पा नामको एक गाउँ रहेको र यस गाउँमा शिवदेवको अनुमति लिएर तात्कालीन सामन्त अंशुवर्माले लिड्वल तथा शोल्ल अधिकरणले गर्ने कुनै काम सम्बन्धी प्रशासनिक आज्ञा जारी गरेको देखिन्छ। अभिलेखको आठौँ पङ्कितमा प्रजाहितविधानम्प्रत्य वाक्य उल्लेख भएको हुँदा यो अभिलेखबाट कर असुल गर्ने भन्दा गाउँबासीलाई कुनै छुट दिइएको वा सुविधा दिएको व्याहोरा उल्लेख भएको अनुमान गर्न सकिन्छ। यसबाट कीर्तिपुर क्षेत्रको पहिलो ज्ञात ऐतिहासिक र प्रमाणित लिच्छवि गाउँ यही बुड्पा गाउँ बन्न पुगेको छ।

खा:सि बजार क्षेत्र : किल्लाबन्द सहरको रूपमा रहेको कीर्तिपुर सहरको दक्षिण तर्फको प्रवेशद्वार बाहिर रहेको क्षेत्र खा:सि बजार हो। कीर्तिपुर सहरको तुलनामा यो क्षेत्र केही नयाँ र ठूला जलाशय युक्त क्षेत्रको रूपमा रहेको पाइन्छ। कीर्तिपुर सहरको दक्षिणी प्रवेशद्वार बाहिर रहे तापनि श्रेष्ठ, प्रधान तथा जोशी जस्ता विशेष नेवार समुदायको धार्मिक र सांस्कृतिक कृयाकलापसँग विशेष सम्बन्धित रहेको छ (Shokoohy, Shokhhhy, \& Shrestha, 2014, p.11)। गोपाल वंशावलीले कीर्तिपुर क्षेत्रलाई शिवदेवले सहर (पुर) को रूपमा विकसित गरेको प्रसंग यस अधि नै उल्लेख भएको छ। धनवज्र वज्राचार्यले पुर हुनका लागि कुनै पनि बस्ती वन, जंगल, पर्खाल र खाइहरूद्वारा किल्ला बन्दी भएको हुनुपर्ने र उक्त क्षेत्रमा (भौतिक) संस्कृतिको विकास भएको हुनु पर्ने बताएका छन् (वि.सं. २०४६, प्. ४५७)। यसबाट १२ औं शताब्दीमा बस्ती विकास गरिएको कीर्तिपुर सहर यहाँको खा:सि बजार क्षेत्रमा रहेका पोखरी तथा पर्खालको भित्रमात्र केन्द्रित भएको देखिन्छ। खा:सि बजार क्षेत्रका ठुला पोखरीहरूका निर्माता पनि शिवदेव नै हुन सक्ने सड्केत पनि वंशावलीबाट पाइन्छ। कीर्तिपुर सहरको किल्ला बाहिर रहेको भए तापनि यस क्षेत्रमा रहेको मध्यकालीन ठुड्गेधारो, ठूला जलाशय युक्त पोखरी एवं यस क्षेत्रका शंकरनारायण एवं उमामहेश्वरका मूर्तिहरूले मध्यकालमै यस क्षेत्रमा पनि मानव बस्ती अवश्य रहेको थियो भन्ने कुराको सङ्केत गर्दछ् ।

लिच्छविकालमा भने यहाँ कुनै मानव बस्ती रहे नरहेको बारेमा कुनै ठोस प्रमाण प्राप्त हुन सकेको छैन । हालसम्म खा:सि बजार क्षेत्रमा लिच्छविकालीन कुनै मूर्ति वा मन्दिर पनि पाइएको छैन। तर हालैको अध्ययनबाट खा:सि बजार क्षेत्रमा रहेको ढुड्गेधारा परिसरमा एउटै प्रस्तरबाट निर्मित एक चैत्यको गर्भभाग (Dome) प्राप्त भएको छ। हर्मिका खण्ड नभएको यस चैत्यको वास्तु शैलीलाई हेर्दा चोभार क्षेत्रमा रहेको लिच्छविकालीन चैत्य तथा चावहिल आदिस्थानबाट प्राप्त एउटै प्रस्तरबाट निर्मित (Monolithic) चैत्य समान देखिन्छ (हेर्नुहोस् : चित्र नं. ७)। यस भौतिक अवशेषलाई आधार मान्दा लिच्छविकालमै खा:सि बजार क्षेत्रमा 
पनि बौद्ध धर्मावलम्बी समुदायको कुनै बस्ती रहेको थियो कि भन्ने अनुमान गर्न सकिन्छ। एउटामात्र भौतिक अवशेषबाट बस्ती रहेको निस्कर्ष निकाल्न नसकिएतापनि भू-बनोटका हिसाबले पानीको स्रोतहरू रहेको, दक्षिणतर्फ खेतीयोग्य फाँट रहेको, चोभार, चारघरे, बाघभैरव तथा उमामहेश्वर क्षेत्रका लिच्छविकालीन बस्तीको बीचमा रहेको आधारमा खा:सि बजार क्षेत्रमा कुनै न कुनै रूपमा लिच्छविकालीन मानव बस्ती रहेको अनुमान गर्नु अन्यथा हुने देखिदैन् ।

ट्याङ्लाफाँट क्षेत्र : पुरानो कीर्तिपुर सहरदेखिपूर्वोत्तर भागमा ट्याड्लाफाँट नामक नयाँबस्ती रहेको छ। कीर्तिपुर नगरपालिका क्षेत्रमा रहेको र त्रिभुवन विश्वविद्यालय परिसरदेखि केही पश्चिमर्फ रहेको यस क्षेत्रमा हालैका केही दशक भित्रमा नयाँ बस्तीको विकास भएको छ। अध्ययनको ऋममा प्राप्त हुन आएका जनविश्वास तथा भौतिक प्रमाणहरूले समेत यस नयाँबस्ती क्षेत्रमा पनि कुनै समय लिच्छविकालीन बस्ती रहेको थियो भन्ने सङ्केत प्राप्त भएको छ।

लेखक प्रयागमान प्रधानले आफ्नो पुस्तकमा यसक्षेत्रसँग सम्बन्धित जनविश्वासहरू संकलन गर्नु भएको छ (ने.सं. ११४०, पृ.१६)। यी जनविश्वास अर्थात् मौखिक परम्पराले यसक्षेत्रलाई लिच्छविकालीन हाँडीगाउँसँग सम्बन्धित देखाएको पाइएको छ। प्रधानले पुस्तकमा उल्लेख गर्नु भए अनुसार हालको हाँडीगाउँ क्षेत्रलाई उपत्यकाका नेवारहरूले 'न:र:' भन्दै आएका छन् । कीर्तिपुरको उत्तरमा पर्ने यस क्षेत्रलाई पनि हाल सम्म स्थानीय बासिन्दाहरूले 'न:र-व:' भन्ने भएकाले हाँडीगाउँ (न:र:) बस्ती यही क्षेत्रबाट बसाई सरी गएका मानिसहरूले बसालेको भन्ने लोकोक्ति वा जन विश्वास कीर्तिपुरबासीमा पाइन्छ। कीर्तिपुर, कुतुऊव: टोलका द्वारे तुयू महर्जनको खेत यही न:र-व क्षेत्रमा रहेको छ। सो खेत नजिकै केही दशकअधि सम्म पोखरी थियो। उक्त पोखरीमा केही समय अघिसम्म पनि हाँडीगाउँमा जस्तै गहना खोज्ने जात्रा हुने गरेको लोकोक्ति कीर्तिपुरमा पाइन्छ। यस प्रकृतिको जात्रा हाँडीगाउँमा यद्यपि चल्दै आएको छ र यसको ऐतिहासिकता लिच्छविकालीन मानिन्छ। यस आधारमा लिच्छविकालमा न:र-व: अर्थात् हालको ट्याड्लाफाँट क्षेत्रमा मानव बस्ती थियो। कुनै कारणले यो बस्ती हाँडीगाउँमा सयो। ठाउँको नाम र गहना खोज्ने जात्राको अवशेष पछिसम्म यहाँ जीवितै रह्यो भन्ने विश्वास यस क्षेत्रका मानिसहरू गर्दछन् (पृ.१६)। अजिमां क्षेत्र कहलाउने अर्को महत्त्वपूर्ण स्थान पनि यसै क्षेत्रभित्र पर्दछ। प्रधानले पुस्तकमा उल्लेख गर्नु भए अनुसार यहाँ विफरको महामारी आउँदा पूजा गर्ने गरिन्छ (पृ.१६)। बालबालिकाका संरक्षिका अजिमा देवी अर्थात् हारतीको अवधारणा नेपालमा दोस्रो-तेस्रो शताब्दीदेखि नै पाइन्छ। यी तथ्यले उक्त स्थानमा लिच्छाविकाल र त्यसपूर्व नै मानव बस्ती भएको कुरालाई सङ्केत गर्दछ् ।

यी आख्यान वा मौखिक परम्परा बाहेक यहाँबाट प्राप्त केही भौतिक प्रमाणहरूले पनि यस क्षेत्रमा लिच्छविकालमा कुनै न कुनै रूपमा मानव बस्तीरहेको सड़केत पाइएको छ। वर्ष द२ का कीर्तिपुर निवासी भक्त महर्जनसँग गरिएको अन्तरवार्ताको सन्दर्भ उल्लेख गर्दै प्रयागमान प्रधानले आफनो पुस्तकमा उक्त स्थानमा निर्माण कार्यको लागि जग खन्ने कममा अग्निशाला, इनार लगायत पक्की इट्टाका (माँ-अप्पा) जगहरू धैरै संख्यामा पाइएको बताएका छन् (प्रधान, ने.सं. १९४०, पृ.१६)। यी अवशेषको वास्तविक तिथि थाहा नभएपनि यो क्षेत्रमा यस अघि पनि मानव बस्ती रहेको कुरा यी अवशेषहरूले पनि पुष्टि गर्दछन्। आधुनिक समयमा मानव बस्ती विनाको खेतीयोगय फाँटमात्र रहेको ट्याङ्लाफाँट क्षेत्र अर्थात् पुरानो न:र-व:क्षेत्रमा हालैको 
दशकमा बनाईएको कुशेश्वर महादेवको एक नयाँ मन्दिर रहेको छ। यस मन्दिर भित्र एक पुरानो शिवलिड्ग रहेको छ। यो शिवलिड्गको जलहारीको गोलोपन, प्रस्तरको रड् र गुणस्तर, आकारको विशालता, र बनावट शैलीलाई लिच्छविकालका अभिलेख सहितका केही शिवलिड्संग तुलनागर्दा समान देखिन्छन् । विजयावतीको सूर्याघाटमा रहेको शिवलिड्ग, पशुपति कैलाश डाँडामा रहेको लिच्छविकालीन भनी पहिचान भएको शिवलिड्ग र लिच्छविकालीन रत्नेश्वर शिवलिड्गको जलहरी खण्डको आकार प्रकार तथा शैलीसँग यहाँको शिवलिड्गको जलहरी समान देखिन्छन् । यस आधारमा यो शिवलिड्गको जलहरी लिच्छविकालीन हुन सक्ने संभावना प्रवल देखिन्छ (हेर्नुहोस् चित्र नं. ६)। स्थानीय बासिन्दाहरूले यो शिवलिड्ग उपेक्षितरूपमा यहीको काडीमा रहेकोमा पछिल्लो समयमा यहाँका नयाँ बासिन्दाहरूले मन्दिर बनाएर यो शिवलिड्ग स्थापना गरेको बताएकाछन् । प्रयागमान प्रधानले पनि आफ्नो पुस्तकमा यस शिवलिड्गलाई लिच्छविकालीन भन्नु भएको छ. (पृ.१६)।

जनविश्वास अनुसार यहाँ रहेको पुरानो बस्ती हाँडीगाउँ क्षेत्रमा बसाइसराई गरेको भन्ने देखिनु, स्थान नामको आधारमा पनि हाँडीगाउँ क्षेत्रसँग यस क्षेत्रको नाम मिल्नु, गहनाखोज्ने जात्राको अस्तित्व केही समय अघिसम्म यहाँ कायम रहेको थियो भन्ने जनविश्वास रहेको देखिनु, हारतीको सम्बन्ध यसक्षेत्रसँग देखिनु र लिच्छविकालीन शिवलिड्गको जलहरीसँग मिल्दो भौतिक प्रमाण यस क्षेत्रमा रहेको देखिएबाट लिच्छाविकालमा यस क्षेत्रमा पनि मानव बसोबास रहेको अनुमान गर्ने आधार प्राप्त भएको छ।

यसरी प्रस्तुत अध्ययनकार्यबाट कीर्तिपुर नगरपालिका क्षेत्र भित्रको बाघभैरव, उमामहेश्वर, चोभार, चारघरे क्षेत्रमा लिच्छविकालीन बस्ती रहेको तथ्य पुष्टि भएको र खा:सि बजार क्षेत्र तथा ट्याझ्लाफाँट क्षेत्रमा पनि लिच्छविकालीन मानव बस्ती रहेको अनुमान गर्न सकिने आधारहरू प्राप्त भएको छ। यी बाहेक कीर्तिपूर नगर क्षेत्रमा हाल घना आवादी भएका पाँगा, इटागोल, नयाँबजार, भाजंगल आदि क्षेत्रमा भने लिच्छविकालका कुनै पनि भौतिक अवशेष, त्यसवेलाका अभिलेख एवं कुनै सांस्कृतिक अभ्यासहरू नपाइएको हुँदा यी क्षेत्रमा लिच्छविकालमा कुनै बस्ती रहेको देखिएन। अर्थात् यी क्षेत्रका पुराना देखिने बस्तीहरू मध्यकालमा विकसित भएको देखिएको छ।

\section{छलफल र निष्कर्ष}

यस अघिको प्राप्ती खण्डमा चर्चा गरिएअनुसार कीर्तिपुरको डाँडोमाथि रहेको सर्वोच्चभाग उमामहेश्वरमन्दिर परिसर र केही पूर्वतर्फको बाघभैरव क्षेत्रमा गोपालहरूको शासनकालदेखि नै निरन्तररूपमा लिच्छविकालसम्म मानव बस्ती रहेको सङ्केत पाइयो। यसै गरी चोभारको आदिनाथ क्षेत्रमा पनि गोपालहरूकै शासनकालदेखि लिच्छविकालसम्म निरन्तररूपले मानव बसोबास रहेको सङ्केत प्राप्त भयो। यी क्षेत्र उच्चभागमा रहेको हुँदा उपत्यकाको पानी बाहिरिए पछि सबैभन्दा पहिले प्रकट भएका भू-क्षेत्र थिए र गोपाल, महिषपाल जस्ता पशुपालक कविलाहरूको लागि पशुपालन गर्न उपयुक्त स्थल थिए । कीर्तिपुर र चोभारको डाँडो गोपालहरूको शासनकालमा पशुपालनका लागि उपयुक्त वनक्षेत्र रहेका थिए र पछि, लिच्छविकालमा आइपुगदा चारैतिर वनले घेरिएका वनदुर्गको रूपमा रहेका थिए। त्यसैले यस क्षेत्रमा गोपालहरूको शासनकालदेखिनै निरन्तर लिच्छविकालसम्म र हालसम्मपनि मानव बस्तीहरू विकसित हुँदै गएको देखिन्छ। गोपाल थरका मानिसहरूको हालसम्मको बसोबास, पुराना धार्मिक र सांस्कृतिक परम्पराहरूमा गोपालीहरूको विशेष सहभागिता, 
गोपालीहरूका धार्मिक कृत्यहरूमा यसक्षेत्रको महत्त्व आदिकुराले यी क्षेत्रमा मानव बसोबासको निरन्तरतालाई थप बलियो बनाएको छ। लिच्छविकालीन भौतिक अवशेषहरूको प्राप्तीले यी क्षेत्रमा लिच्छवि बस्तीले निरन्तरता पाएको कुरालाई नै थप स्पष्ट पारेकाछन् ।

किराँतकालमा यस क्षेत्रमा मानवबसोबास प्रमाणित गर्ने आधार प्राप्त भएको छैन । त्यसैले यस विषयमा थप कुरा भन्न सकिदैन। तर लिच्छविकालको आरम्भपछि डाँडाको शिखरवाट मानव बस्ती ऋमश: तल्लो खेतीयोग्य भागमा विस्तार हुँदै गएको देखिएको छ। लिच्छवि सभ्यता पशुपालक चरणबाट व्यवस्थित कृषि युगमा प्रवेशगरेको उन्नत सभ्यता थियो। त्यसैले पशुपालनमात्र संभव हुने डाँडाको बस्तीहरूवाट तल्लो क्षेत्रमा रहेको खेतीयोग्य जमिनमा लिच्छावि बस्ती विस्तार हुँदै गएको सड्केत यस अध्ययनबाट प्रकाशमा आएको छ।

चारघरे क्षेत्रमा विकसित लिच्छाविकालीन बुड्पागाउँ र त्यसगाउँका बासिन्दाले पन्चापराध सम्बन्धी कार्य गर्ने विश्वास गरिएको शोल्ल अधिकरण र कुलो पानीको बन्दोबस्त मिलाउने कार्यको जिम्मेवारी पाएको लिड्वल अधिकरण मार्फत् पाउने कुनै सुविधा पाएको व्यहोरा उल्लेख भएको अभिलेख पाइएको तथ्यले यस क्षेत्रमा व्यवस्थित खेतीपाती हुनेगरेको कुरालाई नै सङ्केत गरेको छ। यस बाहेक लिच्छविकालका संभावित बस्तीहरू रहेको भनिएको खा:सिबजार क्षेत्र र ट्याङ्ला क्षेत्र पनि खेतीपातीका लागि उपयुक्त फाँट क्षेत्र हुन् । कीर्तिपुरमा सहर बसाउने शिवदेवले खा:सि बजार क्षेत्रमा कुलो एवं पोखरी निर्माण गरेका हुन् भने यसको कारणपनि यस क्षेत्रमा रहेको पुरानो बस्तीको सिचाइ तथा खानेपानी समस्या समाधानकै लागि हुन सक्छ। कृषि सभ्यतामा अभ्यस्त ट्याड़्ला क्षेत्रमा रहेका लिच्छविकालीन बासिन्दाहरू कुनै कारणले घना आवादी भएको हाँडीगाउँ क्षेत्रमा बसाइसराइ गर्नुअघि यसक्षेत्रमा खेतीपातीकै लागि कीर्तिपुर डाँडोबाट यस क्षेत्रमा बस्ती विस्तार गरेको हुन सक्छ।

माथिको छलफलबाट के निष्कर्षमा पुग्न सकिन्छ भने। चोभारको गल्छीबाट उपत्यकाको पानी बाहिरिए पहि कीर्तिपुरको उमामहेश्वर तथा बाघभैरव क्षेत्र र आसपासको क्षेत्र तथा चोभारको आदिनाथ क्षेत्रको उच्च भागमा पशुपालक गोपालहरूको बस्ती बसेको हुन सक्छ। ती क्षेत्रमा लिच्छविकालसम्म पनि मानव बस्तीले निरन्तरता पाएको थियो। लिच्छविकालमा मानव सभ्यता कृषि युगमा प्रवेश गरिसकेपछि, यी स्थलको साथ साथै चारघरे, खा:सिबजार तथा ट्याड्लाफाट क्षेत्रसम्मपनि लिच्छविकालीन बस्ती बसेको हुन सक्ने तथ्यहरू यस अध्ययनबाट प्रकाशमा आएको छ।

\section{सन्दर्भ समग्री सूची}

Bajracharya, D.\& Mall, K.P. (1985). Gopalaraj Bansavali. Kathmandu : Nepal Research Centre.

Bangdel, L.S. (1982).The early sculpture of Nepal. Ghaziabad :Bikash Publishing House.

Gutschow, N. (1997). The Nepalese Caitya : 1500 years of Buddhist votiv archatecture in the Kathmandu valley. London : Edition Axel Menger.

Lock, J.K.(1980). Karunamaya. Kathmandu : Sahayogi prakashan for research centre for Nepal and Asian Studies, Tribhuvan University. 
Maharjan, Y.(2003). A cultural study of Chobhar. An unpublished M. A. thesis submittedon the Tribhuvan University, central department of Nepalese history culture and archaeology .

Maharjan, B.(n.d.) Harisiddhi temple. Retrieved on 31 Oct, 2020 from https://www.academia. edu/7482868/Harisiddhi_Temple

Regmi, D.R.(1983). Inscriptions of ancient Nepal (V01.1) . Delhi : Shaki Malik Abhinav Publications.

Sharma, D.R \& Shrestha,T.B. (2016). Sankhu : Historical and cultural heritage. Kirtipur: Center for Nepal and Asian studies, T.U.

Shokoohy, M.(1994). History. In Shokoohy, M. \& Shokoohy, N.H. (Eds.). Kirtipur: An urban community in Nepal - Its people, town planning, architecture and arts. London : Araxus Books.

Shokoohy,M., Shokoohy, N.H. \& Shrestha, S.S.(2014). Street shrines of Kirtipur, Nepal : As long as the sun and moon endure. London : Araxus books

Shrestha, S.S. (1994). Historic public buildings. In Shokoohy, M. \& Shokoohy, N.H. (Eds.). Kirtipur : An urban community in Nepal - Its people, town planning, architecture and arts. London :Araxus Books.

(1994). Art and antiquities. In Shokoohy, M. \& Shokoohy, N.H. (Eds.). Kirtipur : An urban community in Nepal - Its people, town planning, architecture and arts. London :Araxus Books.

Slusser, M.S. (1982). Nepala Mandala (Vol 1). New Jersey : Princeton Universtty Press .

कीर्ति अध्ययन तथा अनुसन्धान मण्डल (वि.सं. २०७३). कीर्तिपुरको संक्षिप्त चिनारी. कीर्तिपुरः कीर्तिपुर नगरपालिका ।

जोशी, हरिराम (वि.सं. २०३०). नेपालको प्राचीन अभिलेख. काठमाण्डौं: नेपाल राजकीय प्रज्ञा प्रतिष्ठान ।

(वि.सं. २०७०) प्रदिप : अभिनव संस्कृति विश्वकोष. भक्तपुर : वर्कर्स पब्लिकेसन्स् ।

पाण्ड, रामनिवास र रेग्मी, दिनेशचन्द्र (वि.सं. २०४४) नेपालको पौराणिक इतिहास. काठमाडौं : नेपाल र एशियाली अनुसन्धान केन्द्र, त्रि.वि.

प्रधान, प्रयागमान (ने.सं. १९४०) म्हिग:निसे थौ:किपुया छुँ पक्ष. कीपू : कीर्ति रिसर्च सेन्टर।

वज्राचार्य, धनवज्र (वि.सं.२०४३३) लिच्छविकालका अभिलेख (दोस्रो संस्करण). कीर्तिपुरः नेपाल र एशियाली अनुसन्धान केन्द्र, त्रि.वि. ।

------- (वि.सं. २०४६). मध्यकालका अभिलेख. कीर्तिपुर : नेपाल र एशियाली अनुसन्धान केन्द्र, त्रि.वि. । श्रेष्ठ, टेकबहादुर र शर्मा, डिल्लीराज (ने.सं. ११३९). किपू नगरपालिकाय ऐतिहासिक व सांस्कृतिक सम्पदा (कीर्तिपुर नगरपालिकाका ऐतिहासिक र सांस्कृतिक सम्पदा). कीर्तिपुर : नेपाल भाषा एकेडेमी। श्रेष्ठ, शुक्रसागर (वि.सं. २०पू७). कीर्तिपुरको सांस्कृतिक र पुरातात्तिक इतिहास. कीर्तिपुर काठमाण्डौं : नेपाल तथा एशियाली अनुसन्धान केन्द्र, त्रि.वि । 


\section{कीर्तिपुरबाट प्राप्त लिच्छविकालीन कलाकृतिहरूका चित्रहरू}

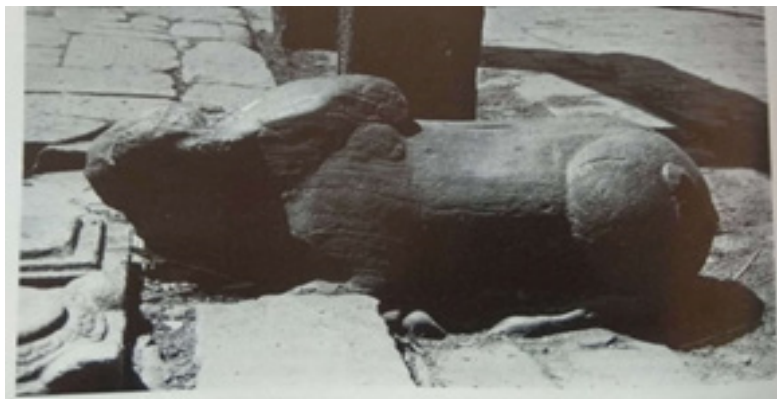

चित्र नं. १: कीर्तिपुर बाघ भैरब मन्दिर अगाडि रहेको नन्दी

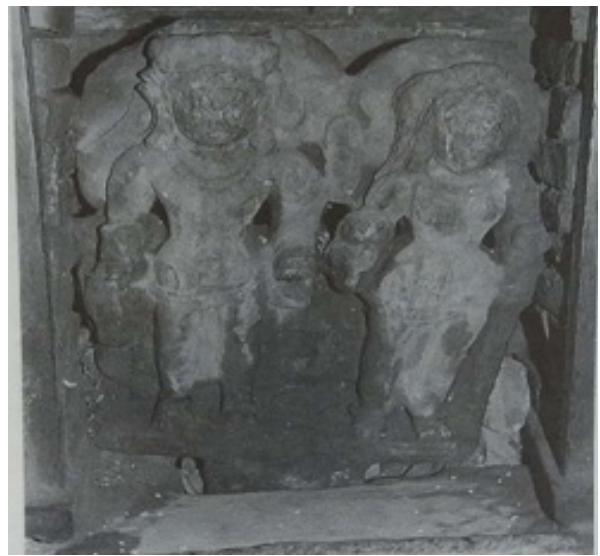

चित्र नं. २ कीर्तिपुर बाघ भैरब मन्दिर अगाडि रहेको गणेश मन्दिर भित्रको उमामहेश्वर मूर्ति फलक

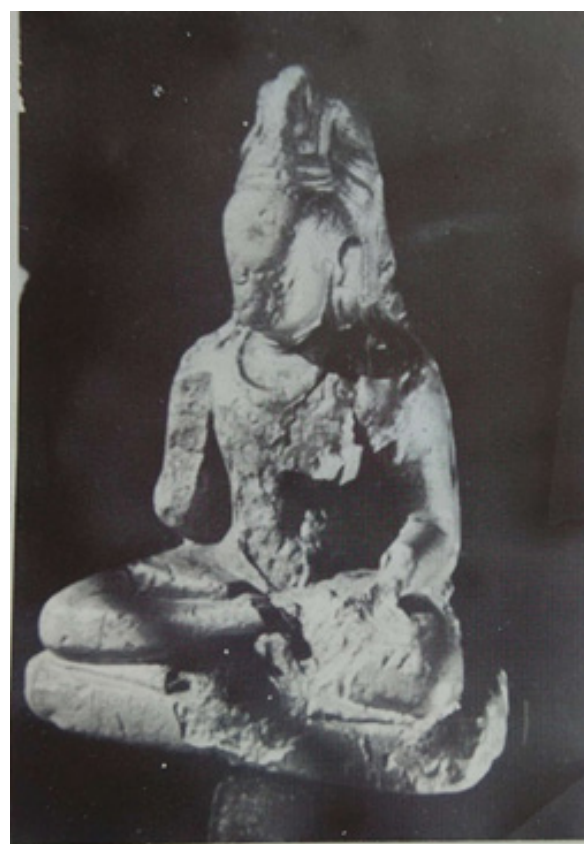

चित्र नं. $\curlyvee$ कीर्तिपुर क्वा: चो बाट प्राप्त शिव मूर्ति (चित्र साभार श्रेष्ठ, वि.सं. २०४७७) 


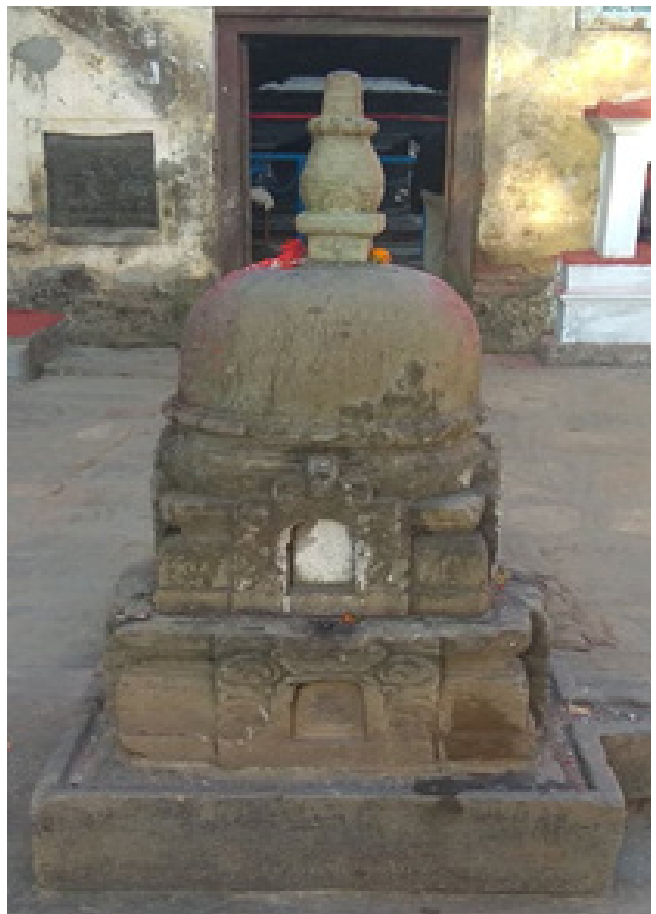

चित्र नं. $y$ चोभार आदिनाथ मन्दिरको पूर्वतर्फ रहेको एउटै प्रस्तरबाट निर्मित चैत्य

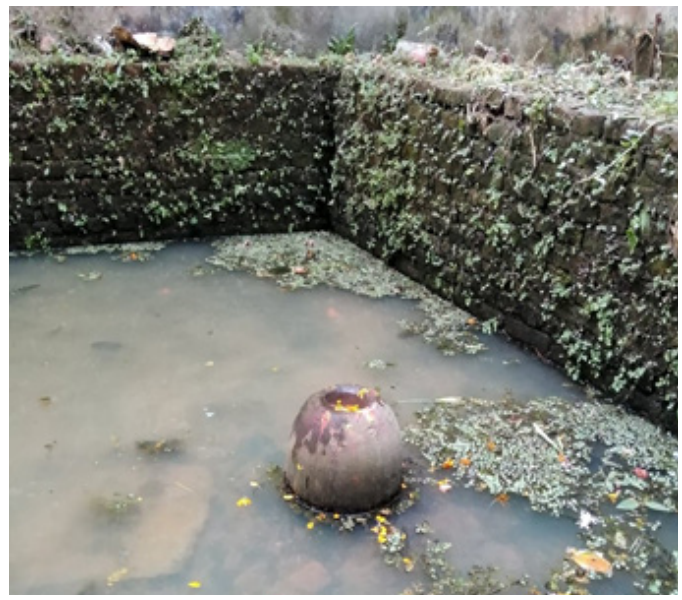

चित्र नं. $७$ कीर्तिपुर खा:सी बजार स्थित ढुड़े धारामा रहेको एउटै प्रस्तरबाट निर्मित चैत्यको गर्भ भाग

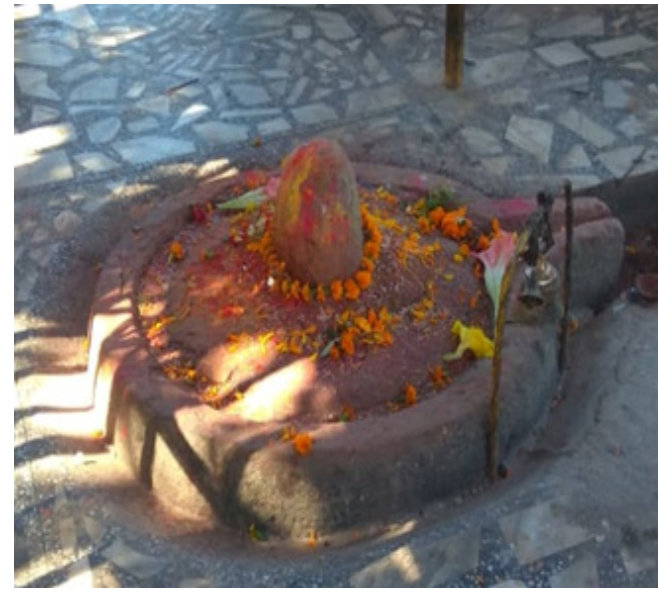

चित्र नं. ६ कीर्तिपुर ट्याड्लाफाँट स्थित कुशेश्वर महादेव मन्दिर भित्र रहेको शिव लिड़ 